\title{
EDITORIAL
}

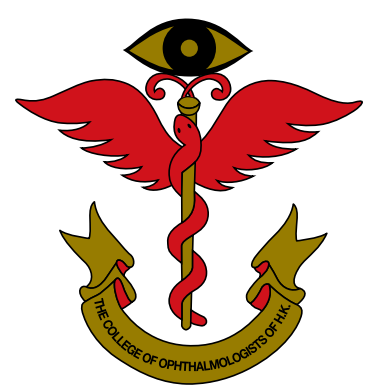

香 港 眼 科 醫 學 院

\section{Antithrombotic treatment in ophthalmic surgery}

Tommy CY Chan ${ }^{1,2}$, FRCSEd, Alex LC Tam ${ }^{3}$, MD, Victoria WY Wong ${ }^{2,4}$, FRCSEd, Ben NM Lam ${ }^{2,4}$ FRCSEd

${ }^{1}$ Department of Ophthalmology, Hong Kong Sanatorium and Hospital, Hong Kong

${ }^{2}$ Department of Ophthalmology and Visual Sciences, The Chinese University of Hong Kong, Hong Kong

${ }^{3}$ Faculty of Medicine, University of Toronto, Canada

${ }^{4}$ Hong Kong Eye Hospital, Hong Kong

Correspondence and reprint requests:

Dr. Tommy CY Chan, Department of Ophthalmology, Hong Kong Sanatorium \& Hospital, 4/F, Li Shu Fan Block, 2 Village Road, Happy Valley, Hong Kong.

E-mail: tommychan.me@gmail.com

Ophthalmic surgery is generally performed in elderly people, many of whom are on systemic medications such as antiplatelet and anticoagulant therapies. These drugs are routinely discontinued preoperatively to prevent severe intra- and post-operative bleeding. Nonetheless, premature discontinuation of antiplatelet therapy or interruption of anticoagulation increases the risk of thromboembolic complications including death. It is important to balance the risk of thrombotic complications and the benefit of avoiding intra- and post-operative bleeding.

Antiplatelet drugs such as aspirin and clopidogrel are prescribed for patients with atherosclerotic vascular disease and/or for prevention of acute coronary syndrome, myocardial infarction, or stroke. Patients with coronary artery disease are often prescribed dual antiplatelet therapy that combines aspirin and clopidogrel for a mandated duration after an acute coronary syndrome or stent (drug-eluting or bare-metal) implantation. Premature discontinuation of antiplatelet therapy may lead to major cardiac complications and thrombotic events (myocardial infarction, stent thrombosis, and non-fatal stroke) and even death. ${ }^{1}$

Anticoagulant treatments such as vitamin $\mathrm{K}$ antagonist (e.g. warfarin) and the novel oral anticoagulants (NOACs) [e.g. dabigatran, rivaroxaban, apixaban, and edoxaban] have been widely used in patients with atrial fibrillation to prevent stroke or systemic embolism, in patients with valvular heart disease after mechanical prosthetic heart valve replacement, and for venous thromboembolism prophylaxis. Patients on anticoagulants are risk-stratified for better perioperative anticoagulant management. The risk of thromboembolic events in patients with a history of atrial fibrillation can be assessed using the CHADS2 score. The thrombotic risk is highest in those with mitral valve prosthesis, older aortic valve prosthesis, and recent stroke or transient ischemic attacks or venous thromboembolic events. As interruption of anticoagulation therapy increases the risk of potentially fatal thromboembolic events, the medical team needs to consider the thrombotic risk based on patient-related and surgeryrelated factors before continuing or stopping anticoagulation. Oral anticoagulants are generally continued perioperatively for minor procedures, whereas invasive procedures may require discontinuation of oral anticoagulants or bridging anticoagulation therapy with subcutaneous low-molecularweight heparin or intravenous unfractionated heparin during interruption of anticoagulation.

Cataract surgery is commonly performed in elderly patients on antithrombotic therapy. The management of antiplatelet and anticoagulation therapies perioperatively in cataract surgery has been well-studied. ${ }^{2-4}$ Cataract removal is an avascular procedure with topical anesthesia, with or without 


\section{EDITORIAL}

intracameral anesthesia. No significantly increased risk of severe bleeding or sight-threatening bleeding complications is associated with antithrombotic treatment, although there may be an increase in the incidence of non-significant or selflimiting hemorrhage such as hyphema or subconjunctival hemorrhage. A Hong Kong study reported no difference in hemorrhagic complications between cases continuing or withholding NOAC during phacoemulsification. ${ }^{5}$

Vitreoretinal (VR) surgery also appears to be safe in patients on antithrombotic therapy. Nonetheless, the literature lacks evidence with strong statistical power to formulate guidelines on perioperative management of antithrombotic therapy for VR surgeries. Anticoagulant drugs are associated with an increased risk of intraocular hemorrhage, but not with serious consequences, re-operations, or surgery failure.$^{6-8}$ In a systematic review and meta-analysis, NOACs were reported to reduce the risk of intraocular bleeding by approximately $20 \%$ when compared with warfarin. ${ }^{9}$ Further studies of the effects of NOACs on the outcome of VR surgery are needed. In patients on warfarin, VR surgery has been shown to result in no anesthesia-related or intraoperative hemorrhagic complications despite some postoperative hemorrhages that resolved spontaneously. Similarly, in systemically anticoagulated patients receiving intravitreal injections, the risk of hemorrhagic complications is extremely low; cessation of anticoagulation therapy is not needed..$^{10-12}$ The benefits of continuing antithrombotic therapy outweigh the risks of discontinuation.

Trabeculectomy or a glaucoma drainage device may result in large variation in intraocular pressure during and after glaucoma surgery. Anticoagulation can thus increase the risk of certain vision-threatening complications such as suprachoroidal hemorrhage. Bleeding can negatively impact the surgical outcome and lead to surgical failure. Intraoperative bleeding, particularly in the subconjunctival space, may impede surgeon visualization of tissues. The proinflammatory nature of bleeding can result in excessive scarring. Blood clots can mechanically block the drainage site at the sclerostomy or tube opening. Patients on anticoagulation therapy have been reported to have an increased postoperative hyphema rate, with or without a significant impact on the final surgical outcome. ${ }^{13,14}$ As the evidence for altering anticoagulation therapy for glaucoma surgery is lacking, different surgeons adopt different practices. Consultation with the primary prescriber of anticoagulation therapy is recommended before alteration.

There is a lack of evidence on which to base guidelines for perioperative management of oculoplastic patients on antithrombotic therapy. The incidence of serious hemorrhagic

\begin{tabular}{|lll|}
\hline Table 1. Perioperative management for antiplatelets & Postoperative resumption \\
\hline Antiplatelet & Timing of last dose before surgery & Next day \\
\hline Aspirin & 5 days & Next day \\
\hline Clopidogrel (non-coronary stent) & 10 days & - Continue if within 6 weeks (bare stent) or 12 months (drug-eluting stent) of stent implantation \\
\hline Clopidogrel (coronary stent) & - Consult physicians if need to be stopped \\
\hline Dural antiplatelets (non-coronary stent) & Continue aspirin and stop clopidogrel 10 days before surgery \\
\hline Dual antiplatelets (coronary stent) & - Avoid surgery within 6 weeks (bare stent) or 12 months (drug-eluting stent) of stent implantation \\
& - Consult physician if need to be stopped \\
\hline Others (e.g. dipyridamole) & Consult physicians \\
\hline
\end{tabular}

\begin{tabular}{|c|c|c|c|}
\hline $\begin{array}{l}\text { Risk of } \\
\text { thrombo- } \\
\text { embolism }\end{array}$ & Management & Bridging therapy & Postoperation \\
\hline Low & $\begin{array}{l}\text { - Omit warfarin } 5 \text { days before surgery } \\
\text { - INR test } 1-2 \text { days before surgery }\end{array}$ & Not applicable & - Resume warfarin $12-24$ hours after surgery \\
\hline \multirow[t]{2}{*}{ Moderate } & No bridging & & \\
\hline & $\begin{array}{l}\text { Consider bridging: } \\
\text { - Omit warfarin } 5 \text { days before surgery } \\
\text { - Daily INR test after warfarin stopped; } \\
\text { start bridging when INR }<1.5\end{array}$ & $\begin{array}{l}\text { Prophylactic dose: } \\
\text { - Enoxaparin } 40 \mathrm{mg} \text { daily subcutaneous } \\
\text { injection; half dose } 1 \text { day before surgery }\end{array}$ & \multirow[t]{2}{*}{$\begin{array}{l}\text { - Resume therapeutic dose enoxaparin and } \\
\text { warfarin according to bleeding risk* } \\
\text { - Daily INR test; stop enoxaparin when INR }>1.5\end{array}$} \\
\hline High & $\begin{array}{l}\text { Need bridging: } \\
\text { - Omit warfarin } 5 \text { days before surgery } \\
\text { - Daily INR test after warfarin stopped; } \\
\text { start bridging when INR }<1.5\end{array}$ & $\begin{array}{l}\text { Therapeutic dose: } \\
\text { - Enoxaparin } 1.5 \mathrm{mg} / \mathrm{kg} \text { daily subcutaneous } \\
\text { injection; half dose } 1 \text { day before surgery }\end{array}$ & \\
\hline
\end{tabular}

Abbreviation: INR = international normalized ratio

* Low risk: resume therapeutic dose of enoxaparin after 24 hours; high risk: delay therapeutic dose of enoxaparin 48 to 72 hours after surgery when there is adequate hemostasis 


\begin{tabular}{|c|c|c|c|}
\hline $\begin{array}{l}\text { Risk of } \\
\text { thrombo- } \\
\text { embolism }\end{array}$ & Mechanical heart valve & $\mathbf{A F}$ & VTE \\
\hline Low & $\begin{array}{l}\text { Bileaflet aortic prosthesis without } \mathrm{AF} \text { and } \\
\text { no other risk factors for stroke }\end{array}$ & $\begin{array}{l}\text { CHADS2 score* of } 0 \text { to } 2 \text { (and no prior } \\
\text { stroke or TIA) }\end{array}$ & $\begin{array}{l}\text { Single VTE occurred }>12 \text { months ago and no other } \\
\text { risk factors }\end{array}$ \\
\hline Moderate & $\begin{array}{l}\text { Bileaflet aortic prosthesis without } \mathrm{AF} \text { and } \\
\text { one of the following: } \mathrm{AF} \text {, prior stoke or } \\
\text { TIA, hypertension, diabetes, congestive } \\
\text { HF, age }>75 \text { years }\end{array}$ & CHADS2 score* of 3 to 4 & $\begin{array}{l}\text { - VTE within past } 3 \text { to } 12 \text { months } \\
\text { - Non-severe thrombophilic conditions } \\
\text { - Recurrent VTE } \\
\text { - Active cancer (treated within } 6 \text { months or palliative) }\end{array}$ \\
\hline High & $\begin{array}{l}\text { - Any mitral valve prosthesis } \\
\text { - Older aortic valve prosthesis } \\
\text { - Recent (within } 6 \text { months) stroke or TIA } \\
\text { - Pregnancy with mechanical heart valve }\end{array}$ & $\begin{array}{l}\text { - CHADS2 score* of } 5 \text { or } 6 \\
\text { - Recent (within } 3 \text { months) stroke or TIA } \\
\text { - Rheumatic valvular heart disease }\end{array}$ & $\begin{array}{l}\text { - Recent (within } 3 \text { months) VTE } \\
\text { - Severe thrombophilia }\end{array}$ \\
\hline
\end{tabular}

Abbreviations: $A F=$ atrial fibrillation, $H F=$ heart failure, $T I A=$ transient ischemic attack, $V T E=$ venous thromboembolism

* CHADS2 score: congestive heart failure (1 point), hypertension (1 point), age $>75$ years ( 1 point), diabetes ( 1 point), and prior stroke or transient ischemic attack ( 2 points)

\begin{tabular}{|c|c|c|}
\hline \multirow[t]{2}{*}{ Novel oral anticoagulant } & \multicolumn{2}{|c|}{ Timing of last dose before surgery } \\
\hline & Standard bleeding risk & High bleeding risk \\
\hline \multicolumn{3}{|l|}{ Creatinine clearance $(\mathrm{mL} / \mathrm{min})^{*}$} \\
\hline \multicolumn{3}{|l|}{ Dabigatran } \\
\hline$>50$ & 24 hours & 2 days \\
\hline$>30$ to $\leq 50$ & 2 days & 4 days \\
\hline$\leq 30$ & 4 days & 6 days \\
\hline \multicolumn{3}{|l|}{ Rivaroxaban } \\
\hline$>30$ & 24 hours & 2 days \\
\hline$<30$ & 2 days & 4 days \\
\hline \multicolumn{3}{|l|}{ Postoperative resumption } \\
\hline Dabigatran (150 mg twice daily $)^{\dagger}$ & Resume 24 hours after surgery & Resume $48-72$ hours after surgery \\
\hline Rivaroxaban (20 mg daily) $^{\dagger}$ & Resume 24 hours after surgery & Resume $48-72$ hours after surgery \\
\hline
\end{tabular}

* (140 - age in years) $x$ mass $(\mathrm{kg}) x$ constant ( 1.23 for men; 1.04 for women) / serum creatinine ( $\mu$ mol/L)

${ }^{\dagger}$ Reduced dose for impaired renal function; for patients at high risk of thromboembolism, consider starting anticoagulant at reduced dose on evening after surgery or the day after

complications secondary to oculoplastic procedures is low. ${ }^{15}$ Patients on antithrombotic agents or not are comparable in terms of perioperative hemorrhagic complications. ${ }^{16}$ In patients undergoing oculoplastic procedures with a greater hemorrhagic risk such as dacryocystorhinostomy or orbital decompression, surgeons generally suggest stopping antithrombotic agents if it is safe to do so. ${ }^{17}$ Alteration of the antithrombotic therapy should be discussed with the patient and individualized based on the nature of surgery and the patient's medical condition and need for anticoagulation.

For most types of ophthalmic procedures, the risks of interrupting antithrombotic therapy appear to outweigh the benefits. Aspirin does not appear to be associated with an increased risk of significant bleeding in patients undergoing any type of ophthalmic surgery. Similarly, warfarin does not appear to increase the risk of bleeding in ophthalmic surgery when the international normalized ratio is within the normal range. In glaucoma or oculoplastic surgeries where bleeding at the operative site may impact the surgical outcome, perioperative alteration of anticoagulation therapy may be performed cautiously and should involve the opinion of a medical specialist. Nonetheless, the evidence on which to base precise recommendations about NOACs is lacking. Further investigations are needed to explore the risk of significant bleeding when altering NOAC therapy.

A collaboration between the Hong Kong Eye Hospital and the Department of Medicine, Queen Elizabeth Hospital aims to design a guideline to standardize and simplify the perioperative antithrombotic management in ophthalmic surgeries. The suggested algorithms for perioperative management of antiplatelet, warfarin, and NOAC therapies are shown in Tables 1 to 4. $^{18-21}$

\section{Declaration}

The authors have no conflicts of interest to disclose. 


\section{References}

1. Rossini R, Capodanno D, Lettieri C, et al. Prevalence, predictors, and long-term prognosis of premature discontinuation of oral antiplatelet therapy after drug eluting stent implantation. Am J Cardiol 2011;107:186-94.

2. Katz J, Feldman MA, Bass EB, et al. Risks and benefits of anticoagulant and antiplatelet medication use before cataract surgery. Ophthalmology 2003;110:1784-8.

3. Kobayashi H. Evaluation of the need to discontinue antiplatelet and anticoagulant medications before cataract surgery. J Cataract Refract Surg 2010;36:1115-9.

4. Barequet IS, Sachs D, Shenkman B, et al. Risk assessment of simple phacoemulsification in patients on combined anticoagulant and antiplatelet therapy. $J$ Cataract Refract Surg 2011;37:1434-8.

5. Cheung JJC, Liu S, Li KKW. Phacoemulsification cataract surgery in patients receiving novel oral anticoagulant medications. Int Ophthalmol 2018 Feb 13 [Epub ahead of print]

6. Narendran N, Williamson TH. The effects of aspirin and warfarin therapy on haemorrhage in vitreoretinal surgery. Acta Ophthalmol Scand 2003;81:38-40.

7. $F u A D$, McDonald HR, Williams DF, et al. Anticoagulation with warfarin in vitreoretinal surgery. Retina 2007;27:290-5.

8. Dayani PN, Grand MG. Maintenance of warfarin anticoagulation for patients undergoing vitreoretinal surgery. Arch Ophthalmol 2006;124:1558-65.

9. Sun MT, Wood MK, Chan W, et al. Risk of intraocular bleeding with novel oral anticoagulants compared with warfarin: a systematic review and meta-analysis. JAMA Ophthalmol 2017;135:864-70.

10. Olson JM, Scott IU, Kerchner DL, et al. Association between systemic anticoagulation and rate of intraocular hemorrhage following intravitreal anti-VEGF therapy for age-related macular degeneration. Ophthalmic Surg Lasers Imaging Retina 2013;44:455-9.
11. Mason JO 3rd, Frederick PA, Neimkin MG, et al. Incidence of hemorrhagic complications after intravitreal bevacizumab (avastin) or ranibizumab (lucentis) injections on systemically anticoagulated patients. Retina 2010;30:1386-9.

12. Dayani PN, Siddiqi OK, Holekamp NM. Safety of intravitreal injections in patients receiving warfarin anticoagulation. Am J Ophthalmol 2007;144:451-3.

13. Cobb CJ, Chakrabarti S, Chadha V, et al. The effect of aspirin and warfarin therapy in trabeculectomy. Eye (Lond) 2007;21:598-603.

14. Law SK, Song BJ, Yu F, et al. Hemorrhagic complications from glaucoma surgery in patients on anticoagulation therapy or antiplatelet therapy. Am J Ophthalmol 2008;145:736-46.

15. Custer PL, Trinkaus KM. Hemorrhagic complications of oculoplastic surgery. Ophthal Plast Reconstr Surg 2002;18:409-15.

16. Kent TL, Custer PL. Bleeding complications in both anticoagulated and nonanticoagulated surgical patients. Ophthal Plast Reconstr Surg 2013;29:113-7.

17. Parkin B, Manners R. Aspirin and warfarin therapy in oculoplastic surgery. Br J Ophthalmol 2000;84:1426-7.

18. Spyropoulos AC, Douketis JD. How I treat anticoagulated patients undergoing an elective procedure or surgery. Blood 2012;120:2954-62.

19. Douketis JD, Spyropoulos AC, Spencer FA, et al. Perioperative management of antithrombotic therapy: Antithrombotic Therapy and Prevention of Thrombosis, 9th ed: American College of Chest Physicians Evidence-Based Clinical Practice Guidelines. Chest 2012;141(2 Suppl):e326S-e350S.

20. Douketis JD, Berger PB, Dunn AS, et al. The perioperative management of antithrombotic therapy: American College of Chest Physicians Evidence-Based Clinical Practice Guidelines (8th Edition). Chest 2008;133(6 Suppl):299S-339S.

21. Vahanian A, Baumgartner H, Bax J, et al. Guidelines on the management of valvular heart disease: The Task Force on the Management of Valvular Heart Disease of the European Society of Cardiology. Eur Heart J 2007;28:230-68. 